\title{
PENERAPAN METODE BERCERITA DENGAN BONEKA TANGAN DALAM MENINGKATKAN KETERAMPILAN MENYIMAK DONGENG SISWA KELAS II SD NEGERI 51 PEKANBARU
}

\author{
Wiwit Nurjanah \\ wiwitnurjanah61@gmail.com \\ Pendidikan Guru Sekolah Dasr FKIP Universitas Riau
}

\begin{abstract}
The background of this research is students who find it difficult to listen to learning. This study aims to determine the differences and increase in students' listening skills using the storytelling method with hand puppets. This research was conducted in class II of SD Negeri 51 Pekanbaru. Based on the results of the study, it was found that there were differences in the skills of listening to fairy tales between the experimental class and the control class. In the final test of the experimental class and the control class obtained $t_{\text {count }}=5.7697 \geq t_{\text {table }}=1.666$, so there are significant differences. Increased skills in listening to fairy tales also occurred in the experimental class from an average of 74, 44 to 86, 94 in the final test and a gain of 0.38 which included in the medium category. So, there is a difference and an increase in the skill of listening to fairy tales grade II students of SD Negeri 51 Pekanbaru using the method of telling stories with hand puppets.
\end{abstract}

Keywords: hand puppets, fairytale listening skills

\section{ABSTRAK}

Latar belakang penelitian ini adalah siswa yang kesulitan mendengarkan pembelajaran. Penelitian ini bertujuan untuk mengetahui perbedaan dan peningkatan keterampilan menyimak siswa menggunakan metode mendongeng dengan boneka tangan. Penelitian ini dilakukan di kelas II SD Negeri 51 Pekanbaru. Berdasarkan hasil penelitian, ditemukan bahwa ada perbedaan keterampilan mendengarkan dongeng antara kelas eksperimen dan kelas kontrol. Pada tes akhir kelas eksperimen dan kelas kontrol diperoleh $t_{\text {hitung }}=5.7697 \geq \mathrm{t}_{\text {tabel }}=1.666$, sehingga ada perbedaan yang signifikan. Peningkatan keterampilan dalam mendengarkan dongeng juga terjadi di kelas eksperimen dari rata-rata 74, 44 menjadi 86, 94 dalam tes akhir dan kenaikan 0,38 yang termasuk dalam kategori sedang. Jadi, ada perbedaan dan peningkatan keterampilan mendengarkan dongeng siswa kelas II SD Negeri 51 Pekanbaru menggunakan metode bercerita dengan boneka tangan.

Kata Kunci: boneka tangan, keterampilan menyimak dongeng

\begin{tabular}{|c|c|c|}
\hline Submitted & Accepted & Published \\
\hline 03 September 2019 & 15 September 2019 & 23 September 2019 \\
\hline
\end{tabular}

\begin{tabular}{|l|c|c|c|}
\hline Citation & $:$ & $\begin{array}{r}\text { Nurjanah, W \& Noviana, E. (2019). Penerapan Metode Bercerita dengan Boneka Tangan dalam Meningkatkan } \\
\text { Keterampilan Menyimak Dongeng Siswa Kelas II SD Negeri 51 Pekanbaru. Jurnal PAJAR (Pendidikan dan } \\
\text { Pengajaran), 3(5), 1180-1187. DOI : http://dx.doi.org/10.33578/pjr.v3i5.7898. }\end{array}$ \\
\hline
\end{tabular}

*Copyright @ 2019 Jurnal PAJAR (Pendidikan dan Pengajaran)

Publish by PGSD FKIP Universitas Riau, Pekanbaru, Indonesia

\section{PENDAHULUAN}

Setiap manusia memiliki keterampilan berbahasa, keterampilan berbahasa yang dimiliki meliputi keterampilan menyimak, membaca, mendengar dan menulis. Keterampilan berbahasa yang sangat berpengaruh adalah keterampilan menyimak. Hal ini dikarenakan keterampilan menyimak membutuhkan konsentrasi yang tinggi untuk memahami suatu pernyataan yang disampaikan secara lisan maupun tulisan.
Keterampilan menyimak haruslah diajarkan dan dikuasai sedini mungkin kepada siswa. Agar pembelajaran keterampilan menyimak menarik bagi siswa, maka keterampilan menyimak diajarkan dengan menggunakan cerita dongeng. Cerita dongeng yang disampaikan akan menarik minat siswa dalam mendengarkan dan memahami isi cerita. Pemahaman anak terhadap keterampilan 
menyimak dongeng ini, sangatlah bergantung kepada cara penyampaian guru dalam mengajar. Guru haruslah kreatif dalam mengembangkan keterampilan bahasa siswa, dimana guru haruslah menggunakan metode yang menarik perhatian.

Menurut Fadlillah (2014: 58-59) penggunaan metode kreatif oleh guru dikarenakan anak suka bermain dan guru haruslah mengisi keseharian belajar anak dengan aktivitas bermain, dengan dasar inilah muncul istilah belajar sambil bermain atau bermain sambil belajar hal ini menunjukkan bahwa bermain erat kaitannya dengan dunia anak-anak.

Ada beberapa faktor yang menyebabkan pengembangan keterampilan menyimak sulit untuk dilakukan, yaitu: kurangnya konsentrasi yang dimiliki siswa, penggunaan metode ceramah oleh guru, kurangnya partisipasi siswa di dalam pembelajaran dan tidak adanya kegiatan bermain sambil belajar yang dilakukan oleh guru.

Permasalahan di atas terdapat solusi untuk mengatasinya, yaitu dengan menggunakan metode bercerita dengan boneka tangan. Pembelajaran menggunakan boneka tangan diperkirakan dapat menumbuhkan konsentrasi, menciptakan pembelajaran yang kondusif, siswa terhindar dari kebosanan dan menarik perhatian siswa agar terfokus terhadap cerita dongeng yang disampaikan oleh guru.

Menurut Lu Fei, et al (2011) "Fantasy storytelling play was found essential for children's development. In addition to accommodating almost unlimited creative imagination, fantasy storytelling offers a space for children to take different roles in their play, allowing various group interactions and collaborations to emerge and potentially be transferred into the real life". Permainan mendongeng fantasi ditemukan penting untuk

\section{KAJIAN TEORETIS}

Metode cerita ialah metode yang mengisahkan suatu peristiwa atau kejadian kepada siswa. Kejadian atau peristiwa tersebut disampaikan kepada siswa melalui tutur kata, ungkapan dan mimik wajah yang unik (Fadlillah, 2014). perkembangan anak-anak. Selain mengakomodasi imajinasi kreatif yang hampir tak terbatas, mendongeng fantasi menawarkan ruang bagi anak-anak untuk mengambil peran berbeda dalam permainan mereka, memungkinkan berbagai interaksi kelompok dan kolaborasi muncul dan berpotensi ditransfer ke dalam kehidupan nyata.

Rumusan masalah pada penelitian ini adalah "Apakah terdapat perbedaan menggunakan metode bercerita dengan boneka tangan terhadap keterampilan menyimak dongeng siswa kelas II SD Negeri 51 Pekanbaru? dan apakah terdapat peningkatan menggunakan metode bercerita dengan boneka tangan terhadap keterampilan menyimak dongeng siswa kelas II SD Negeri 51 Pekanbaru?". Pada penelitian ini memiliki tujuan untuk mengetahui adanya perbedaan menggunakan metode bercerita dengan boneka tangan terhadap keterampilan menyimak dongeng siswa kelas II SD Negeri 51 Pekanbaru dan mengetahui adanya peningkatan menggunakan metode bercerita dengan boneka tangan terhadap keterampilan menyimak dongeng siswa kelas II SD Negeri 51 Pekanbaru. Penelitian ini juga dapat memberikan manfaat kepada beberapa pihak yaitu: (1) bagi guru, memberikan saran pengembangan pembelajaran yang kreatif, menarik dan dapat meningkatkan keterampilan menyimak dongeng siswa pada pembelajaran bahasa Indonesia; (2) bagi siswa, meningkatkan keaktifan dan konsentrasi dalam pembelajaran bahasa Indonesia materi menyimak dongeng dan meningkatkan keterampilan menyimak isi dongeng pada pembelajaran bahasa Indonesia; (3) bagi sekolah, memberikan saran yang positif terhadap kemajuan sekolah dengan menggunakan metode bercerita dengan boneka tangan, khususnya pembelajaran bahasa Indonesia materi menyimak dongeng.

Menurut Kurnia (2009) ada beberapa langkah dalam metode bercerita, yaitu: 1) anak memperhatikan guru menyiapkan alat peraga yang diperlukan; 2) anak mengatur posisi tempat duduknya; 3) anak memperhatikan guru menunjukkan alat peraga yang sudah disiapkan dan menyebutkan nama dan tokoh-tokoh dalam 
cerita; 4) guru menyebutkan judul cerita; 5) anak mendengarkan guru bercerita dengan melaksanakan dialog dan dialog antar boneka; 6) sambil bercerita, guru menggerakkan boneka tangan secara bergantian sesuai isi cerita; 7) setelah selesai bercerita, guru memperlihatkan kembali seluruh boneka tangan secara bergantian; 8) anak menyimpulkan isi cerita; dan 9) guru melengkapi kesimpulan isi cerita.

Menurut Mariana dan Zubaidah (2015) media boneka dipilih dalam pembelajaran bercerita karena dalam bercerita siswa harus mempunyai ide atau bahan cerita, keberanian, penguasaan bahasa, dan ekspresi. Penggunaan media boneka dapat menjadi alternatif sekaligus inovasi bagi guru dalam menumbuhkan siswa dalam bercerita. Media boneka sangat menarik bagi siswa karena dengan boneka siswa dapat termotivasi untuk berimprovisasi, baik dari segi kebahasaan maupun nonkebahasaan. Boneka mampu mengembangkan minat siswa agar belajar dalam bercerita. Boneka dapat memberikan kesempatan kepada siswa untuk mengembangkan kreativitas dan keterampilan dramatiknya.

Menurut Daryanto dalam Ayu (2016) menyatakan bahwa boneka dapat diklasifikasikan ke dalam lima jenis yaitu: 1) boneka jari, merupakan boneka yang dimainkan dengan menggunakan jari-jari tangan; 2) boneka tangan,merupakan boneka yang dimainkan dengan menggunakan tangan dimana jari berfungsi sebagai pendukung gerakan boneka; 3) boneka tongkat, merupakan boneka yang dimainkan dengan menggunakan tongkat atau kayu seperti wayang-wayangan; 4) boneka tali, merupakan boneka yang gerakan tubuhnya melalui tali yang menghubungkan kepala, tangan, dan kaki; 5) boneka bayang-bayang, merupakan boneka yang dimainkan dengan cara mempertontonkan gerak bayang-bayang boneka.

Boneka tangan adalah boneka yang digerakkan dari bawah oleh seseorang yang tangannya dimasukkan kebawah pakaian boneka (Nana Sudjana dan Ahmad Rivai, 2007)

Menurut Cung, et al (2012) "Hand puppets, which can be found in many countries including the UK, China and Taiwan, are used as facilitators in collaborative storytelling. Hand puppetry may be a potential approach to addressing the affective, cognitive and social barriers encountered in collaborative storytelling". Boneka tangan, yang dapat ditemukan di banyak negara termasuk Inggris, Cina dan Taiwan, digunakan sebagai fasilitator dalam cerita bersama. Boneka tangan mungkin merupakan pendekatan potensial untuk mengatasi hambatan afektif, kognitif dan sosial yang ditemui dalam dongeng kolaboratif.

Menurut Gunarti dalam Sugianto (2017) penggunaan boneka tangan sebagai media pembelajaran mempunyai banyak manfaat, yaitu: 1) penggunaan boneka tangan dapat menarik minat dan perhatian siswa; 2) penggunaan boneka tangan tidak memerlukan tempat yang luas dan waktu yang lama; 3) dapat melatih imajinasi dan kreatifitas anak.

Menurut Iskandaswassid dan Dadang Sunendar (2008) keterampilan menyimak adalah suatu bentuk keterampilan berbahasa yang bersifat reseptif. Sedangkan menurut Tarigan (2015) menyimak merupakan suatu proses menerima lambang-lambang lisan dengan penuh perhatian, pemahaman, apresiasi dan interpretasi untuk memperoleh informasi, menangkap isi atau pesan, serta memahami makna komunikasi yang telah disampaikan oleh si pembicara melalui ujaranujaran atau bahasa lisan.

Mendongeng adalah kegiatan untuk menyampaikan pesan atau informasi menarik kepada pendengarnya. Dapat disampaikan menggunakan alat peraga seperti boneka tangan, gambar, atau boneka jari (Ans, 2014).

Mei 2019. Jenis penelitian merupakan penelitian kuantitatif yang bertujuan untuk mengetahui perbedaan dan peningkatan keterampilan Peneliti melaksanakan penelitian di kelas
II Sekolah Dasar Negeri 51 Pekanbaru di
Kelurahan Rintis, Kecamatan Lima Puluh
Penelitian dilaksanakan pada bulan April sampai Peneliti melaksanakan penelitian di kelas
II Sekolah Dasar Negeri 51 Pekanbaru di
Kelurahan Rintis, Kecamatan Lima Puluh.
Penelitian dilaksanakan pada bulan April sampai Peneliti melaksanakan penelitian di kelas
II Sekolah Dasar Negeri 51 Pekanbaru di
Kelurahan Rintis, Kecamatan Lima Puluh.
Penelitian dilaksanakan pada bulan April sampai

\section{METODE PENELITIAN} Peneliti melaksanakan penelitian di kelas
II Sekolah Dasar Negeri 51 Pekanbaru di
Kelurahan Rintis, Kecamatan Lima Puluh.
Penelitian dilaksanakan pada bulan April sampai 
menyimak dongeng menggunakan metode bercerita dengan boneka tangan siswa kelas II.

Metode penelitian yang digunakan adalah eksperimen semu (quasi experimental), dengan desain nonequivalent control groups design. Nonequivalent control groups design, terdiri dari kelompok eksperimen dan kelompok kontrol yang tidak dipilih secara random tetapi menerima keadaan kelas apa adanya (Sugiyono, 2016).

Subjek penelitian ini adalah siswa kelas

II B SD Negeri 51 Pekanbaru tahun ajaran

\section{HASIL DAN PEMBAHASAN}

Adapun perolehan hasil penelitian mengenai keterampilan menyimak dongeng siswa kelas II SD Negeri 51 Pekanbaru adalah sebagai berikut:
2018/2019 yang berjumlah 36 siswa dan siswa kelas II C SD Negeri 51 Pekanbaru tahun ajaran 2018/2019 yang berjumlah 37 siswa.

Teknik pengumpulan data yang dilakukan adalah teknik observasi dan teknik tes. Teknik observasi dengan melakukan pengamatan pengajaran bahasa Indonesia, kurikulum, RPP, metode dan silabus yang digunakan di SD Negeri 51 Pekanbaru. Sedangkan teknik tes, dilakukan untuk mengambil data keterampilan menyimak dongeng.

Skor Tes Awal (Pretest)

Tabel 1. Data Tes Awal Kelas Eksperimen dan Kelas Kontrol

\begin{tabular}{ccccccc}
\hline Kelas & $\begin{array}{c}\text { Jumlah } \\
\text { Siswa } \\
(\mathbf{n})\end{array}$ & $\begin{array}{c}\text { Rata-rata } \\
\text { Tes Awal } \\
(\overline{\boldsymbol{x}})\end{array}$ & $\begin{array}{c}\text { Standar } \\
\text { Deviasi } \\
(\mathbf{s})\end{array}$ & $\begin{array}{c}\text { Varian } \\
\left(\boldsymbol{s}^{\mathbf{2}}\right)\end{array}$ & $\begin{array}{c}\text { Nilai } \\
\text { Min }\end{array}$ & $\begin{array}{c}\text { Nilai } \\
\text { Max }\end{array}$ \\
\hline Eksperimen & 36 & 74.44 & 14.43 & 208.25 & 50 & 100 \\
Kontrol & 37 & 89.19 & 9.83 & 96.55 & 70 & 100 \\
\hline
\end{tabular}

Berdasarkan tabel diatas dapat diketahui bahwa terdapat perbedaan rata-rata hasil belajar siswa pada tes awal (pretest) antara kelas eksperimen dan kelas kontrol. Hasil rata-rata kelas eksperimen adalah 74.44 dan rata-rata pada kelas kontrol adalah 89.19. Rata-rata tes awal pada kelas eksperimen lebih rendah dibandingkan rata-rata tes awal kelas kontrol.

Skor Tes Akhir (Postest)

Tabel 2. Data Tes Akhir Kelas Eksperimen dan Kelas Kontrol

\begin{tabular}{ccccccc}
\hline Kelas & $\begin{array}{c}\text { Jumlah } \\
\text { Siswa } \\
(\mathbf{n})\end{array}$ & $\begin{array}{c}\text { Rata-rata } \\
\text { Tes Akhir } \\
(\overline{\boldsymbol{x}})\end{array}$ & $\begin{array}{c}\text { Standar } \\
\text { Deviasi } \\
(\mathbf{s})\end{array}$ & $\begin{array}{c}\text { Varian } \\
\left(\boldsymbol{s}^{\mathbf{2}}\right)\end{array}$ & $\begin{array}{c}\text { Nilai } \\
\text { Min }\end{array}$ & $\begin{array}{c}\text { Nilai } \\
\text { Max }\end{array}$ \\
\hline Eksperimen & 36 & 86.94 & 10.91 & 118.97 & 70 & 100 \\
Kontrol & 37 & 70.54 & 13.53 & 183.03 & 50 & 90 \\
\hline
\end{tabular}

Berdasarkan tabel diatas dapat diketahui bahwa rata-rata hasil belajar siswa setelah diberikan perlakuan, kelas eksperimen mendapatkan hasil rata-rata lebih tinggi dibandingkan kelas kontrol. Hasil rata-rata tes akhir kelas eksperimen sebesar 86.94 dan kelas kontrol sebesar 70.54. Hal tersebut membuktikan bahwa pembelajaran menggunakan metode bercerita dengan boneka tangan lebih baik dibandingkan pembelajaran dengan menggunakan audio.

Tingkat Keterampilan 
Tabel 3. Tingkatan Keterampilan Kelas Eksperimen dan Kelas Kontrol

\begin{tabular}{cccc}
\hline Sumber Data & Kelas & Rata-rata & Tingkat Keterampilan \\
\hline Pretest & Eksperimen & 74.44 & Terampil \\
& Kontrol & 89.19 & Sangat Terampil \\
Postest & Eksperimen & 86.94 & Sangat Terampil \\
& Kontrol & 70.54 & Terampil \\
\hline
\end{tabular}

Berdasarkan tabel diatas dapat diketahui bahwa tingkat keterampilan yang dimiliki kelas eksperimen dan kelas kontrol berbeda. Tes awal kelas eksperimen memiliki rata-rata 74.44 yang termasuk dalam tingkat terampil dan mengalami peningkatan pada tes akhir yang memiliki ratarata 86.94 yang termasuk dalam tingkat sangat terampil. Sedangkan rata-rata tes awal kelas kontrol adalah 89.19 yang termasuk dalam tingkat sangat terampil dan mengalami penurunan pada tes akhir yang memiliki rata-rata 70.54 yang termasuk dalam tingkat terampil.

\section{Uji Hipotesis}

Tabel 4. Hasil Uji Hipotesis Kelas Eksperimen dan Kelas Kontrol

\begin{tabular}{cccc}
\hline Sumber Data & $\boldsymbol{t}_{\text {hitung }}$ & $\boldsymbol{t}_{\text {tabel }}$ & Keterangan \\
\hline $\begin{array}{c}\text { Tes Awal Eksperimen - Tes } \\
\text { Awal Kontrol }\end{array}$ & -19.780 & 1.666 & Tidak terdapat perbedaan yang \\
signifikan \\
$\begin{array}{c}\text { Tes Akhir Eksperimen - Tes } \\
\text { Akhir Kontrol }\end{array}$ & 5.7697 & 1.666 & Terdapat perbedaan yang signifikan \\
\hline
\end{tabular}

Berdasarkan tabel diatas dapat diketahui bahwa hasil uji hipotesis keterampilan menyimak dongeng pada tes awal menunjukkan bahwa $t_{\text {hitung }}=-19.780 \leq t_{\text {tabel }}=1.666$, maka tes awal kelas kontrol dan kelas eksperimen tidak terdapat perbedaan yang signifikan dan kemampuan awal siswa kedua kelas adalah sama. Sedangkan pada tes akhir kelas kontrol dan kelas eksperimen dari hasil uji-t adalah $t_{\text {hitung }}=5.7697 \geq t_{\text {tabel }}=$
1,666, maka pada tes akhir ini terdapat perbedaan yang signifikan. Hal ini menunjukkan bahwa penggunaan metode bercerita dengan boneka tangan secara signifikan dapat meningkatkan kemampuan menyimak dongeng dibandingkan menggunakan pembelajaran dengan audio.

\section{Uji Gain}

Tabel 5. Hasil Uji Gain Kelas Eksperimen dan Kelas Kontrol

\begin{tabular}{ccccc}
\hline Kelas & Tes Awal & Tes Akhir & Gain & Kategori \\
\hline Eksperimen & 74.44 & 86.94 & 0.38 & Sedang \\
Kontrol & 89.19 & 70.54 & -1.76 & Terjadi Penurunan \\
\hline
\end{tabular}

Berdasarkan tabel diatas dapat dilihat bahwa terjadi peningkatan skor pembelajaran keterampilan menyimak dongeng pada kelas eksperimen dan penurunan pada kelas kontrol. Pada kelas eksperimen rata-rata skor tes awal (pretest) siswa yaitu 74.44 dan setelah diberikan perlakuan rata-rata tes akhir (postest) keterampilan menyimak dongeng menjadi 86.94 dengan gain 0.38 yang termasuk kategori sedang.
Sedangkan pada kelas kontrol terjadi penurunan skor keterampilan menyimak dongeng dari ratarata tes awal (pretest) yaitu 89.19 menurun menjadi 70.54 pada tes akhir (postest) dengan gain -1.76 yang termasuk kategori terjadi penurunan. Dengan demikian keterampilan menyimak dongeng menggunakan metode bercerita dengan boneka tangan lebih baik dan lebih efektif daripada menggunakan media audio. 
Berdasarkan hasil penelitian yang diperoleh, dapat disimpulkan bahwa terdapat perbedaan keterampilan menyimak dongeng antara kelas eksperimen dan kelas kontrol. Dengan hasil uji-t diperoleh $t_{\text {hitung }}=5.7697$ dan $t_{\text {tabel }}=1.666$ sehingga terdapat perbedaan yang signifikan terhadap nilai posttest kelas eksperimen dan kelas kontrol. Dan terdapat peningkatan keterampilan menyimak dongeng pada kelas eksperimen dengan nilai tes awal sebesar 74.44 menjadi 86.94 dengan rata-rata peningkatan sebesar 0.38 yang termasuk kategori sedang.

\section{Pembahasan}

Dari hasil uji perbedaan rata-rata tes awal diketahui bahwa rata-rata kelas eksperimen adalah 74.4 dan rata-rata kelas kontrol adalah 89.19. Berdasarkan rata-rata tes awal kelas eksperimen dan kelas kontrol, diketahui tidak memiliki perbedaan yang signifikan. Berdasarkan hasil uji-t kelas eksperimen dan kelas kontrol pada tes awal memiliki $t_{\text {hitung }}=-19.780$ dan $t_{\text {tabel }}=1.666$, sehingga tes awal siswa kelas eksperimen dan kelas kontrol memenuhi kriteria $t_{\text {hitung }}<t_{\text {tabel }}$. Hal ini menunjukkan bahwa tidak terdapat perbedaan pada keterampilan menyimak dongeng sebelum diberikan perlakuan.

Setelah mengalami proses pembelajaran sebanyak dua kali pertemuan dikelas eksperimen dan kelas kontrol, selanjutnya siswa dari kelas eksperimen dan kelas kontrol diberikan tes akhir (postest). Pemberian tes akhir (postest) bertujuan untuk mengetahui perbedaan dan peningkatan menggunakan metode bercerita dengan boneka tangan terhadap pembelajaran keterampilan menyimak dongeng pada kelas eksperimen dan kelas kontrol dalam pembelajaran keterampilan menyimak dongeng setelah diberikannya perlakuan.

Berdasarkan perbedaan rata-rata tes akhir dapat dilihat bahwa terdapat perbedaan yang signifikan terhadap keterampilan menyimak dongeng antara siswa yang belajar menggunakan metode bercerita dengan boneka tangan dan siswa yang belajar dengan menggunakan audio. Perbedaan ini dibuktikan dengan dengan perhitungan uji-t tes akhir kelas eksperimen yaitu $t_{\text {hitung }}=5.7697$ dan $t_{\text {tabel }}=1.666$, yang berarti terdapat perbedaan keterampilan menyimak dongeng yang signifikan antara siswa yang belajar menggunakan metode bercerita dengan boneka tangan dan siswa yang belajar dengan menggunakan audio. Perbedaan yang signifikan terhadap keterampilan menyimak dongeng pada tes akhir disebabkan oleh perlakuan yang berbeda, pada kelas eksperimen diberikan perlakuan pembelajaran menggunakan metode bercerita dengan boneka tangan, sedangkan pada kelas kontrol diberikan perlakuan menggunakan audio.

Setelah dilakukan uji-t untuk mengetahui perbedaan tes akhir kelas eksperimen dan kelas kontrol, selanjutnya dilakukan uji gain untuk mengetahui peningkatan keterampilan menyimak dongeng sebelum dan sesudah perlakuan. Dari hasil analisis gain pada kelas eksperimen memperoleh 0.38 yang termasuk kategori sedang dan untuk kelas kontrol adalah -1.76 yang termasuk dalam kategori terjadi penurunan.

Berdasarkan penelitian yang telah dilakukan, bahwa rata-rata keterampilan menyimak dongeng pada kelas eksperimen mengalami peningkatan dari rata-rata tes awal 74 . 44 menjadi 86.94 pada tes akhir dan pada kelas kontrol terjadi penurunan dari rata-rata tes awal 89.19 menjadi 70.54 pada tes akhir. Setelah dilakukannya perhitungan statistik, diketahui adanya perbedaan keterampilan menyimak dongeng antara kelas eksperimen dan kelas kontrol. Hal ini menunjukkan bahwa metode bercerita dengan boneka tangan dapat digunakan untuk meningkatkan keterampilan menyimak dongeng.

Peningkatan pada kelas eksperimen terjadi karena bimbingan guru yang seiring dengan aktivitas belajar yang dilakukan siswa. Penerapan metode bercerita dengan boneka tangan memberikan pembelajaran untuk siswa mengembangkan pemahamannya terhadap isi dan pesan terhadap yang telah dilihat dan didengarnya. Berbeda dengan pembelajaran menggunakan audio pada kelas kontrol, informasi hanya berpusat pada yang didengar saja oleh siswa. Dalam proses pembelajaran siswa hanya pasif menerima informasi yang didengar saja. Hal ini menyebabkan siswa sulit untuk menerima 
pembelajaran, kesulitan siswa dalam menerima pembelajaran inilah yang berdampak pada pada keterampilan menyimak dongeng.

Berdasarkan pembahasan hasil penelitian dapat disimpulkan bahwa hipotesis yang diajukan

\section{SIMPULAN DAN REKOMENDASI}

Berdasarkan dari hasil dan pembahasan penelitian, maka dapat disimpulkan bahwa penerapan metode bercerita dengan boneka tangan secara signifikan memiliki perbedaan terhadap kemampuan menyimak dongeng siswa dibandingkan dengan pembelajaran dengan audio. Sesuai dengan hasil uji-t diperoleh $t_{\text {hitung }}=$ 5.7697 dengan taraf signifikan $\alpha=0.05$. Dengan ketentuan jika $t_{\text {hitung }}>t_{\text {tabel }}$ maka Ha diterima, jika $t_{\text {hitung }}<t_{\text {tabel }}$ maka Ha ditolak. Data menunjukkan bahwa nilai $t_{\text {hitung }}=5.7697>$ $t_{\text {tabel }}=1.666$ sehingga $\mathrm{Ha}$ diterima dan $\mathrm{Ho}$ ditolak. Dengan demikian, terdapat perbedaan keterampilan menyimak dongeng antara kelas eksperimen dan kelas kontrol.

Hasil pada penelitian ini juga menyimpulkan bahwa terjadi peningkatan yang signifikan terhadap keterampilan menyimak dongeng antara kelas eksperimen yang menggunakan metode bercerita dengan boneka tangan dan terjadi penurunan terhadap kelas kontrol yang menggunakan audio. Dengan jumlah

\section{DAFTAR PUSTAKA}

Ans, H. (2014). Origami Boneka Jari. Yogyakarta: Rainbow.

Ayu, W. (2016). Pengaruh Media Boneka Tangan Terhadap Keterampilan Menyimak Cerita Kelas IIB SD Negeri Margoyasan. Jurnal Pendidikan Guru Sekolah Dasar, 27(5), 580-586.

Chung, et al. (2012). Applying Tangible Story Avatars To Enhance Children's Collaborative

Storytelling. Journal of Educational Technology, 43(1), 39-51.

Desy, S. (2017). Peningkatan Kemampuan Menyimak Dongeng Melalui Pembelajaran Menggunakan Media dapat diterima. Dengan demikian secara signifikan terdapat perbedaan dan peningkatan keterampilan menyimak dongeng menggunakan metode bercerita dengan boneka tangan pada siswa kelas II SD Negeri 51 Pekanbaru.

peningkatan keterampilan menyimak dongeng pada kelas eksperimen sebesar 0.38 yang termasuk kategori sedang dan jumlah penurunan keterampilan menyimak dongeng pada kelas kontrol sebesar -1.76. Dengan demikian, terdapat peningkatan keterampilan menyimak dongeng pada kelas eksperimen yang menggunakan metode bercerita dengan boneka tangan.

Berdasarkan pada pemaparan simpulan di atas, maka peneliti memberikan rekomendasi sebagai berikut:

1. Untuk meningkatkan keerampilan menyimak dongeng siswa disekolah, diharapkan guru kelas untuk lebih sering menggunakan modifikasi dan kreasi cara mengajar.

2. Kepada peneliti selanjutnya adar meneliti lebih dalam lagi mengenai perbedaan-perbedaan yang terjadi antara kelas ekperimen dan kelas kontrol serta hubungan antara metode bercerita dengan boneka tangan terhadap keterampilan menyimak dongeng siswa.

Boneka Tangan. Scholaria, 7(2), 179189.

Fadlillah, M. (2014). Desain Pembelajaran PAUD. Jogjakarta: Ar-Ruzz Media.

Iskandarwassid dan Sunendar, D. (2008). Strategi Pembelajaran Bahasa. Bandung: Rosdakarya.

Joko, S. (2014). Profil Cerita Anak Dan Media Boneka Tangan Dalam Metode Bercerita Berkarakter untuk Siswa SD. Mimbar Sekolah Dasar, 1(2), 113-122.

Kartini, D. (2016). Penerapan Metode Bercerita Menggunakan Boneka Tangan dalam Meningkatkan Kemampuan Menyimak pada Anak. Bahasantodea, 4(2), 28-37. 
Kurnia, R. (2009). Metodologi Pengembangan Bahasa Anak Usia Dini. Pekanbaru: Cendikia Insani.

Lu, et al. (2011). ShadowStory: Creative and Collaborative Digital Storytelling Inspired by Cultural

Heritage. Session. (Online). www.scholar.google.com. (diakses 1 September 2019)

Mariana, S dan Zubaidah, E. (2015). Pengaruh Penggunaan Media Boneka Tangan Terhadap Keterampilan Bercerita Siswa
Kelas V Sd Se-Gugus 4 Kecamatan Bantul. Jurnal Prima Edukasia, 3(2): 166-176.

Sudjana, N. Rivai, A. (2009). Media Pengajaran. Bandung: Sinar Baru Algensindo.

Sugiono. (2016). Metode Penelitian Pendidikan. Bandung: Alfabeta.

Tarigan, H. (2015). Menyimak Sebagai Suatu Keterampilan Berbahasa. Bandung: CV Angkasa. 